\title{
Chemical composition of commercial tambaqui (Colossoma macropomum) cuts in different body weight classes (Amazon: Brazil)
}

Composição química de cortes comerciais de tambaqui (Colossoma macropomum) em diferentes classes de peso corporal (Amazônia: Brasil)

Composición química de cortes comerciales de gamitana (Colossoma macropomum) en diferentes clases de peso corporal (Amazonía: Brasil)

Jucilene Cavali

ORCID: https://orcid.org/0000-0002-2069-4543 Universidade Federal de Rondônia, Brazil E-mail: jcavali@unir.br

Carla Taveira Nunes

ORCID: https://orcid.org/0000-0001-7494-5670 Universidade Federal de Rondônia, Brazil E-mail: nutricao@facsaopaulo.edu.br

Jerônimo Vieira Dantas Filho

ORCID: https://orcid.org/0000-0002-5965-9438 Universidade Federal do Acre, Brazil E-mail: jeronimovdantas@gmail.com

Beatriz Andrade Nóbrega

ORCID: https://orcid.org/0000-0003-2713-3295

Universidade Federal de Rondônia, Brazil E-mail: policarpoandrade@gmail.com

Rute Bianchini Pontuschka

ORCID: https://orcid.org/0000-0002-3789-1252

Universidade Federal de Rondônia, Brazil E-mail: rutepont@unir.br

Renato Zanella

ORCID: http://orcid.org/0000-0002-5971-1785

Universidade Federal de Santa Maria, Brazil E-mail: renato.zanella@ufsm.br

Márcia Cristina Araújo Santana

ORCID: https://orcid.org/0000-0001-9040-5009 Instituto Federal de Educação, Ciência e Tecnologia Baiano, Brasil E-mail: marcia.santana@ifbaiano.edu.br

Maria Luiza Rodrigues de Souza ORCID: https://orcid.org/0000-0003-1135-6443 Universidade Estadual de Maringá, Brazil E-mail: mlrsouzauem@gmail.com

Marlos Oliveira Porto

ORCID: https://orcid.org/0000-0002-9398-0065 Universidade Federal de Rondônia, Brazil E-mail: marlosporto@unir.br

\begin{abstract}
It is important to know the nutritional composition of the fish, especially the nutritional value of the commercial cuts most consumed by the population. The aimed of this study was to evaluate the chemical composition of commercial tambaqui (Colossoma macropomum) cuts in different classes of body weight. The sample collections were carried out in processing units in two municipalities in the state of Rondônia, Brazil. The Data on 200 fish were recorded, with weight ranging from 1000 to $4700 \mathrm{~g}$. Five classes of body weight were established, class 1 - below $1.2 \mathrm{~kg}$; class 2 from 1.21 to $1.8 \mathrm{~kg}$; class 3 - from 1.81 to $2.4 \mathrm{~kg}$; class 4 - from 2.41 to $3.5 \mathrm{~kg}$; class 5 - over $3.5 \mathrm{~kg}$. The commercial cuts were lyophilized and intended for chemical analysis. The Kruskal-Wallis test $(\alpha=0.05)$ was used to compare the averages. The composition of commercial cuts was different in weight classes $(p<0.05)$. The filet presented more representative values in mineral matter, crude protein and total lipids and lower humidity for class 4 (from 2.41 to 3.5 $\mathrm{kg}$ ). The classes 1 and 5 (below 1.2 and over $3.5 \mathrm{~kg}$ ) were different $(\mathrm{p}<0.05)$ in relation to the lipid and moisture content in the commercial filet and rib cuts. The tambaqui steak in class 4 have a higher lipid content compared to the average of the lightest body weight classes, 9.99 vs $4.50 \%$, in addition to having a lower moisture content $(\mathrm{p}<0.05)$. The tambaqui band was different $(\mathrm{p}<0.05)$ in relation to nutritional components between body weight classes, with
\end{abstract}


class 4 being richer in minerals, crude protein and lipids in dry matter. Therefore, the class 4 was the most efficient $(\mathrm{p}<0.05)$ for production and commercialization. Because the tambaquis with body weight between 2.4 to $3.5 \mathrm{~kg}$ stood out in relation to the nutritional components in the different commercial cuts.

Keywords: Bromatological evaluation; Fish farming; Nutritional atributes; Nutritional composition.

\begin{abstract}
Resumo
É importante conhecer a composição nutricional do pescado, principalmente o valor nutritivo dos cortes comerciais mais consumidos pela população. O objetivo deste estudo foi avaliar a composição química de cortes comerciais de tambaqui (Colossoma macropomum) de diferentes classes de peso corporal. As coletas amostrais foram realizadas em unidades de processamento em dois municípios do estado de Rondônia, Brasil. Foram registrados os dados de 200 peixes, com peso variando de 1000 a $4700 \mathrm{~g}$. Foram estabelecidas cinco classes de peso corporal, classe 1 - abaixo de $1,2 \mathrm{~kg}$; classe 2 - de 1,21 a 1,8 kg; classe 3 - de 1,81 a 2,4 kg; classe 4 - de 2,41 a 3,5 kg; classe 5 - acima de 3,5kg. Os cortes comerciais foram liofilizados e destinados à análise química. $\mathrm{O}$ teste de Kruskal-Wallis $(\alpha=0,05)$ foi utilizado para comparar as médias. A composição dos cortes comerciais foi diferente nas classes de peso $(p<0,05)$. $\mathrm{O}$ filé apresentou valores mais representativos em matéria mineral, proteína bruta e lipídios totais e menor umidade para a classe 4 (de 2,41 a 3,5 kg). As classes 1 e 5 (abaixo de 1,2 e acima de 3,5 kg) foram diferentes $(\mathrm{p}<0,05)$ em relação ao teor de lipídios e umidade nos cortes comerciais de filé e costela. A posta de tambaqui da classe 4 apresenta maior teor de lipídios em relação à média das classes de peso corporal mais leve, 9,99 vs 4,50\%, além de apresentar menor teor de umidade $(\mathrm{p}<0,05)$. A banda do tambaqui foi diferente $(\mathrm{p}<0,05)$ em relação aos componentes nutricionais entre as classes de peso corporal, sendo a classe 4 mais rica em minerais, proteína bruta e lipídios na matéria seca. Portanto, a classe 4 foi a mais eficiente $(p<0,05)$ para produção e comercialização. Porque os tambaquis com peso entre 2,4 a $3,5 \mathrm{~kg}$ se destacaram em relação aos componentes nutricionais nos diferentes cortes comerciais.
\end{abstract}

Palavras-chave: Avaliação bromatológica; Atributos nutricionais; Composição nutricional; Piscicultura.

\title{
Resumen
}

Es importante conocer la composición nutricional del pescado, especialmente el valor nutricional de los cortes comerciales más consumidos por la población. El objetivo de este estudio fue evaluar la composición química de cortes comerciales de tambaqui (Colossoma macropomum) de diferentes clases de peso. Las recolecciones de muestras se llevaron a cabo en unidades de procesamiento en dos municipios del estado de Rondônia, Brasil. Se registraron datos sobre 200 peces, con un peso que oscilaba entre 1000 y $4700 \mathrm{~g}$. Se establecieron cinco clases de peso corporal, clase 1: menos de 1,2 kg; clase 2 - de 1,21 a $1,8 \mathrm{~kg}$; clase 3 - de 1,81 a 2,4 kg; clase 4 - de 2,41 a 3,5 kg; clase 5 - más de $3,5 \mathrm{~kg}$. Los cortes comerciales fueron liofilizados y destinados al análisis químico. Se utilizó la prueba de Kruskal-Wallis $(\alpha=0.05)$ para comparar las medias. La composición de los cortes comerciales fue diferente en las clases de peso $(\mathrm{p}<0.05)$. El filete presentó valores más representativos en materia mineral, proteína cruda y lípidos totales y menor humedad para la clase 4 (de 2,41 a 3,5 kg). Las clases 1 y 5 (por debajo de 1,2 y más de 3,5 $\mathrm{kg}$ ) fueron diferentes $(\mathrm{p}<0,05)$ en relación con el contenido de lípidos y humedad en los cortes comerciales de filetes y costillas. Las rodajas de tambaqui de clase 4 tienen un contenido de lípidos más alto que el promedio de las clases de peso corporal más livianas, 9.99 vs $4.50 \%$, además de tener un contenido de humedad menor (p<0.05). La banda de tambaqui fue diferente $(\mathrm{p}<0.05)$ en relación a los componentes nutricionales entre las clases de peso corporal, siendo la clase 4 más rica en minerales, proteína cruda y lípidos en materia seca. Por lo tanto, la clase 4 fue la más eficiente $(\mathrm{p}<0.05)$ para producción y comercialización. Porque los tambaquis que pesaban entre 2,4 a 3,5 $\mathrm{kg}$ se destacaron en relación a los componentes nutricionales en los diferentes cortes comerciales.

Palabras clave: Atributos nutricionales; Composición nutricional; Evaluación bromatológica; Piscicultura.

\section{Introduction}

The fish is an excellent food, from a nutritional and economic point of view, and can be considered a functional food (Botelho et al., 2017). It is one of the main sources of animal protein for the world population (FAO, 2018). The fish meat in general is rich in amino acids (Sales and Maia, 2013), and an important source of fatty acids, proteins and minerals (Lima et al., 2018). It has characteristics such as easy digestibility due to proteins of high biological value (Batalha et al., 2017).

The tambaqui Colossoma macropomum (Cuvier, 1818) belongs to the Actinopterygii class, order Characiformes and family Characidae, and occurs naturally in the Amazon River basin (Dória et al., 2012). The main points that lead to the widespread use of this species for the practice of aquaculture activity are an ease of obtaining juveniles, excellent development, productivity and market acceptance (Cirne et al., 2019; Valenti et al., 2021). Its nutritional values vary in 1 to $2 \%$ of minerals, 15 to $24 \%$ of protein, 0.1 to $22 \%$ of fat and 70 to $85 \%$ of moisture (Oliveira et al., 2019; Dantas Filho et al., 2021). 
The global demand for fish has undergone a significant increase in recent decades, mainly due to population growth and the search for consumers for healthier foods (FAO, 2018; Valenti et al., 2021). In this context, fish farming appears as a viable alternative to continue increasing supply in the coming years (Brabo et al., 2016; Martins et al., 2020). Among the countries with potential, the Brazil has a prominent role, mainly due to water availability, favorable climate and natural occurrence of aquatic species that make zootechnical and market interests compatible (BRASIL, 2013). However, fish consumption in the country is still below the world average, the national average consumption of fish in 2018 was $12 \mathrm{~kg}$ per capita, however, some points in the Amazon region recorded, in the same year, consumption above $150 \mathrm{~kg}$ per capita (FAO, 2018; Costa Junior et al., 2018).

The state of Rondônia is the largest producer of native fish in Brazil, accounting for $47.5 \%$ of the production of a total of 68.8 thousand tons of native fish in 2019 (Peixe BR, 2020), and has tambaqui (Colossoma macropomum) as the most cultivated species (Meante \& Dória, 2017; Porto et al., 2021). These results were achieved due to climatic conditions, the proximity of a large consumer market, added to the high availability of water, highlight Rondônia in Brazilian aquaculture production (Meante \& Dória, 2017). It is worth mentioning that the water condition, added to cultural and socioeconomic factors, has favored and presented in fish farming, a significant growth which, in recent years, has been highlighted by its expansion, investment and profitability (Costa et al., 2015; Martins et al., 2020).

The balanced foods are essential for the success of commercialization, however the costs of captive feeding, depending on the managed production system, can reach $80 \%$ of the total costs (Martins et al., 2020; Porto et al., 2020; Porto et al., 2021). In this sense, it is important to carry out evaluations of zootechnical indexes, mainly with regard to feed conversion and carcass yields (Cavali et al., 2020). The planning of production, investment, costs and manufacturing, presupposes prior knowledge of yields and parts to be processed (Cavali et al., 2020), thus providing data regarding the efficiency of production and the processing company (Menezes et al., 2010; Dantas Filho et al., 2021).

Based on the above context, it is important to know the chemical composition of the fish, above all, the nutritional value of the cuts most consumed by the population, so that the commercial value can be valued and recognized. As well as nutritionally categorizing the tambaqui weight ranges for commercialization, with the intention of guaranteeing safe information to the consumer. Whereas, knowing the chemical composition of commercial cuts allows evaluations of effectiveness in nutritional transfer and also the technical and technological averages to be used for the best processing, in addition to adding commercial value and diversifying the processing of native species of the Amazon (Oliveira et al., 2019; Dantas Filho et al., 2021).

The aimed of this study was to evaluate the chemical composition of commercial filet, ribs, steak and band of tambaqui (Colossoma macropomum) commercial cuts in different classes of body weight marketed in the Western Amazon.

\section{Material and Methods}

This study was conducted by the Physico-chemical and Microbiological Analysis Laboratory of the Universidade Federal de Rondônia (UNIR), with the support of the Rondônia Research Support Foundation (FAPERO) and approved by the Ethics Committee on the Use of Animals (CEUA) with protocol number 02/2017. The sample collections were carried out from May/2017 to December/2018 at two fish processing units in the state of Rondônia, in the municipalities of Ariquemes and Vale do Paraíso. Both registered in the Brazilian System for the Inspection of Products of Animal Origin (SISBI-POA).

There five classes were established for tambaqui in relation to body weight, class 1 - below $1.2 \mathrm{~kg}$; class 2 - from 1.21 to $1.8 \mathrm{~kg}$; class 3 - from 1.81 to $2.4 \mathrm{~kg}$; class 4 - from 2.41 to $3.5 \mathrm{~kg}$; class 5 - over $3.5 \mathrm{~kg}$. There 200 tambaquis with body weight ranging from $1 \mathrm{~kg}$ to $4.7 \mathrm{~kg}$ were studied. From these classes, the commercial cuts of filet, rib, steak and band were evaluated, making up 10 fish per commercial cut destined to the analysis of the chemical composition. 


\subsection{The sampling of commercial cuts and processing}

The sampled specimens were selected from fish farms previously characterized, excluding batches of production systems that adopted productive management very different from that adopted in fish farms, such as reports of parasite infestations, deaths from high stocking densities, undernutrition, among others. The fish were removed from the tanks through a fishing net, and then went through the process of stunning by concussion, then they were euthanized by exsanguination by section of the carotid veins, according to procedures adopted by the fish processing units. In the processing industry, the fish were washed, gutted and processed in commercial cuts according to market demand (Figure 1).

The slaughtered fish were destined for commercial rib and filet cuts (Figure $1 \mathrm{a}$ and $\mathrm{b}$ ), were preceded by the removal of the spine on the evisceration table followed by the removal of intramuscular spines and separation of the respective commercial cuts. Using the band saw, the commercial cut was prepared (Figure $1 \mathrm{c}$ ). For commercial band cutting (Figure $1 \mathrm{~d}$ ) the head was kept, with only the spines and fins removed. Samples of the commercial cuts of tambaqui were taken from different body fractions, in order to obtain greater representativeness of the commercial cut.

Figure 1 - Representation of commercial cuts of tambaqui processed in slaughterhouses in Rondônia, Brazil. (a) filet; (b) rib; (c) steak; (d) band.

(a)

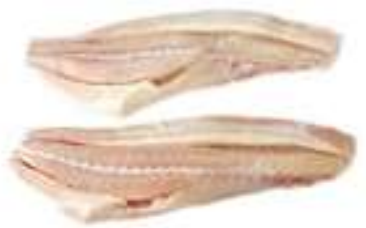

(c)

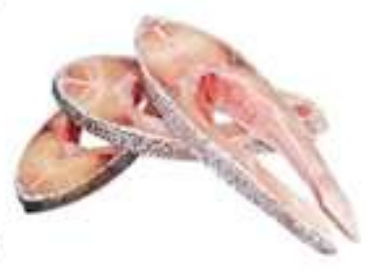

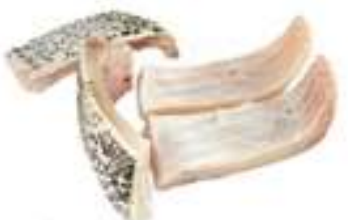

(b)

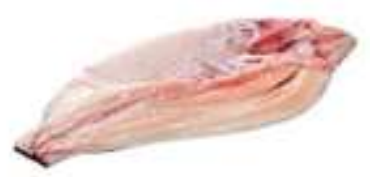

(d)

Source: Authors.

The samples destined to the analysis of the chemical composition were obtained from the homogenization of three points of the commercial cut in order to obtain greater representativeness. The samples were properly identified and stored at $18^{\circ} \mathrm{C}$ for further processing and analysis of the chemical composition. They were left labeled and frozen in a freezer at $-18^{\circ} \mathrm{C}$ until the moment of chemical composition analysis.

\subsection{Chemical composition assessment}

The samples of the commercial cuts were weighed and stored at $5^{\circ} \mathrm{C}$ for 12 hours, were cut into $1 \mathrm{~cm}^{2}$ pieces, placed in previously weighed and identified aluminum lunch boxes, and frozen at $-20^{\circ} \mathrm{C}$ for 48 hours. And, to evaluate the chemical composition, a LIOTOP L101 lyophilizer was used for 44 hours. In the chemical evaluation, freeze-drying was carried out to subsequently obtain the content of dry matter, mineral matter and crude protein (Detmann et al., 2012). To evaluate the total lipids, 3.5g of the lyophilized sample were used and the lipids were extracted using ethanol and chloroform (Brum et al., 2009). It is worth mentioning that the chemical composition analyzes of commercial cuts were carried out in duplicates. To evaluate the total lipids, $3.5 \mathrm{~g}$ of the lyophilized sample were used and the lipids were extracted using ethanol and chloroform (Brum et al., 2009). 


\subsection{Statistical analysis}

The experimental design was completely randomized with four commercial cuts for the processing of tambaqui in five classes of body weight, the processing being carried out in triplicate. To compare the averages of chemical composition between the weight classes, first the data were conducted to the Shapiro-Wilk and Levene test $(\alpha=0.05)$ to verify normality and homogeneity, then we opted for the non-parametric test analysis, the Kruskal-Wallis test $(\alpha=0.05)$ for comparing the averages of chemical composition between weight classes and commercial cuts. The software used to perform the statistical analyzes was the Genes Program made available by the Universidade Federal de Viçosa (UFV), version 13.3 (Cruz, 2013), it is worth mentioning that the statistical program $\mathrm{R}$ was linked to facilitate the interpretation of the results.

\section{Results}

The chemical composition of the tambaqui filet was different between weight classes ( $<<0.05$ ). The class 4 (from 2.41 to $3.5 \mathrm{~kg}$ ), presented more representative values of mineral matter, crude protein, total lipids and lower humidity $(\mathrm{p}<0.05)$. The class 5 (over $3.5 \mathrm{~kg}$ ), was characterized by low moisture content and a lower amount of mineral matter and total lipids when compared to other body weight classes. However, the classes 4 and 5 (from 2.41 to 3.5 and above $3.5 \mathrm{~kg}$ ) showed higher values of crude protein (Table 1). This result may be related to the tendency to have a higher dry matter content or to the reduction of body tissue moisture with the animal's maturity (Baldisserotto, 2013).

The total lipid contents of the filet of class 1 and 5 (below 1.2 and above $3.5 \mathrm{~kg}$ ) showed lower values than the other weight classes. The class 1 are younger fish and class 5 had a lower total lipid content due to the processing adopted, because fish in class 5 have high levels of body fat, and need a toilet or more rigorous cleaning to produce the filet. An important characteristic shown in Table 1 was the intermediate classes, since mineral matter, crude protein and total lipids did not differ statistically ( $>0.05$ ), varying only the humidity. The average nutritional differences are between Classes 1 and 5 (below 1.2 and over $3.5 \mathrm{~kg}$ ), which indicates that these categories are not the most interesting for the industry, and above all, for the consumer, because their nutritional attributes are unsatisfactory to the market.

Table 1 - Chemical composition (g/100g) of commercial cut filet of tambaqui in different classes of body weight.

\begin{tabular}{|c|c|c|c|c|c|}
\hline Weight classes & Mineral matter ${ }^{1}$ & Crude protein & Total lipids & Moisture & $n$ \\
\hline 1 (below $1.2 \mathrm{~kg}$ ) & $1.06 \mathrm{ab}$ & $17.64 \mathrm{~b}$ & $5.74 \mathrm{~b}$ & $75.54 \mathrm{a}$ & 10 \\
\hline $2(1.21$ to $1.8 \mathrm{~kg})$ & $1.16 \mathrm{ab}$ & $18.33 \mathrm{~b}$ & $6.18 \mathrm{~b}$ & $74.30 \mathrm{a}$ & 19 \\
\hline $3(1.81$ to $2.4 \mathrm{~kg})$ & $1.04 \mathrm{ab}$ & $16.87 \mathrm{~b}$ & $8.50 \mathrm{ab}$ & $73.57 \mathrm{a}$ & 14 \\
\hline $4(2.41$ to $3.5 \mathrm{~kg})$ & $1.59 \mathrm{a}$ & $23.86 \mathrm{ab}$ & $10.64 \mathrm{a}$ & $63.89 \mathrm{~b}$ & 18 \\
\hline 5 (over $3.5 \mathrm{~kg})$ & $0.87 \mathrm{~b}$ & $28.47 \mathrm{a}$ & $11.14 \mathrm{a}$ & $67.52 \mathrm{ab}$ & 10 \\
\hline C. V. $(\%)^{2}$ & 40.19 & 25.08 & 54.29 & 11.20 & - \\
\hline
\end{tabular}

(a, b) - in each column, means followed by different letters, differ by the Kruskal-Wallis test $(\mathrm{p}<0,05) .{ }^{1}$ Mineral material: total iron, sodium, potassium, calcium and magnesium. ${ }^{2}$ C.V. - coefficient of variation. Source: Authors.

The chemical composition of the tambaqui rib differed $(\mathrm{p}<0.05)$ in terms of lipid and moisture content between classes 1 and 5 (below 1.2 and above $3.5 \mathrm{~kg}$ ). The class 4 (from 2.41 to $3.5 \mathrm{~kg}$ ), was characterized by low levels of moisture and higher levels of mineral matter, crude protein and total lipids compared to other classes of body weight (Table 2). 
Table 2 - Chemical composition $(\mathrm{g} / 100 \mathrm{~g})$ of commercial cut rib of tambaqui in different classes of body weight.

\begin{tabular}{|c|c|c|c|c|c|}
\hline Weight classes & Mineral matter ${ }^{1}$ & Crude protein & Total lipids & Moisture & $n$ \\
\hline 1 (below $1.2 \mathrm{~kg}$ ) & $1.52 \mathrm{a}$ & $19.37 \mathrm{a}$ & $3.25 \mathrm{~b}$ & $75.84 \mathrm{a}$ & 11 \\
\hline $2(1.21$ to $1.8 \mathrm{~kg})$ & $1.47 \mathrm{a}$ & $18.76 \mathrm{a}$ & $4.91 \mathrm{~b}$ & $74.85 \mathrm{a}$ & 10 \\
\hline $3(1.81$ to $2.4 \mathrm{~kg})$ & $1.47 \mathrm{a}$ & $18.76 \mathrm{a}$ & $4.91 \mathrm{~b}$ & $74.85 \mathrm{a}$ & 10 \\
\hline $4(2.41$ to $3.5 \mathrm{~kg})$ & $1.69 \mathrm{a}$ & $20.66 \mathrm{a}$ & $8.61 \mathrm{ab}$ & $69.02 \mathrm{~b}$ & 13 \\
\hline 5 (over $3.5 \mathrm{~kg})$ & $1.33 \mathrm{~b}$ & $19.04 \mathrm{a}$ & $10.42 \mathrm{a}$ & $69.19 \mathrm{~b}$ & 10 \\
\hline C.V. $(\%)^{2}$ & 26.72 & 20.19 & 50.33 & 7.74 & - \\
\hline
\end{tabular}

$(\mathrm{a}, \mathrm{b})$ - in each column, means followed by different letters, differ by the Kruskal-Wallis test ( $<<0.05) .{ }^{1}$ Mineral material: total iron, sodium, potassium, calcium and magnesium. ${ }^{2}$ C.V. - coefficient of variation. Source: Authors.

The tambaqui steak was different from the other commercial cuts in terms of crude protein, lipids and moisture content $(\mathrm{p}<0.05)$ (Table 3). The cut is the commercial cut considered to be low in fat (Cartonilho \& Jesus, 2011), corresponding transversally to the body structure of the fish, it does not have the same acceptance when compared to the filet and the rib due to the intramuscular spines in the form of "y". It was not possible to obtain the class 5 for the steak, since the processing units use fish of the category above $3.5 \mathrm{~kg}$ for filet and rib processing. The class $4 \mathrm{drummers} \mathrm{(over} 2.4 \mathrm{~kg}$ ) had a higher lipid content compared to the average of the lightest body weight classes, $9.99 \%$ vs $4.50 \%$, in addition to having a lower moisture content $(\mathrm{p}<0.05)$ (Table 3$)$.

Table 3 - Chemical composition (g/100g) of commercial cut steak of tambaqui in different classes of body weight.

\begin{tabular}{|c|c|c|c|c|c|}
\hline Weight classes & Mineral matter ${ }^{1}$ & Crude protein & Total lipids & Moisture & $n$ \\
\hline 1 (below $1.2 \mathrm{~kg}$ ) & $1.48 \mathrm{a}$ & $18.39 \mathrm{a}$ & $4.32 \mathrm{~b}$ & $75.80 \mathrm{a}$ & 10 \\
\hline $2(1.21$ to $1.8 \mathrm{~kg})$ & $1.28 \mathrm{~b}$ & $18.29 \mathrm{a}$ & $4.46 \mathrm{~b}$ & $75.95 \mathrm{a}$ & 10 \\
\hline $3(1.81$ to $2.4 \mathrm{~kg})$ & $1.49 \mathrm{a}$ & $16.55 \mathrm{~b}$ & $4.81 \mathrm{~b}$ & $77.13 \mathrm{a}$ & 16 \\
\hline $4(2.41$ to $3.5 \mathrm{~kg})$ & $1.50 \mathrm{a}$ & $19.31 \mathrm{a}$ & $9.99 \mathrm{a}$ & $69.18 \mathrm{~b}$ & 10 \\
\hline C.V. $(\%)^{2}$ & 28.32 & 16.01 & 55.41 & 6.42 & - \\
\hline
\end{tabular}

$(\mathrm{a}, \mathrm{b})$ - in each column, means followed by different letters, differ by the Kruskal-Wallis test $(\mathrm{p}<0.05) .{ }^{1}$ Mineral material: total iron, sodium, potassium, calcium and magnesium. ${ }^{2}$ C.V. - coefficient of variation. Source: Authors.

Unlike the other commercial cuts analyzed, the tambaqui band showed a difference $(\mathrm{p}<0.05)$ between nutritional components (Table 4). The band is characterized by being a part resulting from the division of the whole tambaqui carcass, where the filet, rib and steak are found. The class 4 (from 2.4 to $3.5 \mathrm{~kg}$ ), stood out nutritionally with higher levels of minerals, crude protein and total lipids in dry matter $(\mathrm{p}<0.05)$, that is, more nutrients per $\mathrm{kg}$ of weight body weight $($ Table 4$)$. It is inferred that this commercial cut would be the most advantageous to the consumer, since he would be acquiring fractions of the other cuts discussed previously. It is also inferred that this weight class is suitable for the type of commercial cut, being one of the reasons why the tambaqui band, in this weight category, is ideal and evident for its production and commercialization.

Tabela 4 - Chemical composition $(\mathrm{g} / 100 \mathrm{~g})$ of commercial cut band of tambaqui in different classes of body weight.

\begin{tabular}{|c|c|c|c|c|c|}
\hline Classes de peso & Mineral matter ${ }^{1}$ & Crude protein & Total lipids & Moisture & $n$ \\
\hline 1 (below $1.2 \mathrm{~kg}$ ) & $1.29 \mathrm{ab}$ & $18.38 \mathrm{ab}$ & $4.54 \mathrm{~b}$ & $75.78 \mathrm{a}$ & 11 \\
\hline $2(1.21$ to $1.8 \mathrm{~kg})$ & $1.27 \mathrm{ab}$ & $18.30 \mathrm{ab}$ & $5.39 \mathrm{~b}$ & $75.04 \mathrm{a}$ & 11 \\
\hline $3(1.81$ to $2.4 \mathrm{~kg})$ & $1.25 \mathrm{ab}$ & $17.80 \mathrm{~b}$ & $6.77 \mathrm{ab}$ & $74.17 \mathrm{a}$ & 10 \\
\hline $4(2.41$ to $3.5 \mathrm{~kg})$ & $1.73 \mathrm{a}$ & $23.21 \mathrm{a}$ & $10.46 \mathrm{a}$ & $64.59 \mathrm{~b}$ & 13 \\
\hline 5 (over3.5 kg) & $1.10 \mathrm{~b}$ & $17.76 \mathrm{~b}$ & $10.78 \mathrm{a}$ & $74.35 \mathrm{a}$ & 10 \\
\hline C.V. $(\%)^{2}$ & 30,32 & 17,03 & 58,31 & 8,21 & - \\
\hline
\end{tabular}

$(\mathrm{a}, \mathrm{b})$ - in each column, means followed by different letters, differ by the Kruskal-Wallis test $(\mathrm{p}<0.05) .{ }^{1}$ Mineral material: total iron, sodium, potassium, calcium and magnesium. ${ }^{2}$ C.V. - coefficient of variation. Source: Authors. 


\section{Discussion}

Lima et al. (2018) when analyzing the yields and chemical composition of tambaqui in different commercial cuts of three body weight categories (category I: $>2.000 \mathrm{~g}$, II: $1.500-1.000 \mathrm{~g}$ and III: $<500 \mathrm{~g}$ ), obtained $77.4 \%$ of humidity for the commercial filet cut showed no difference between weight categories $(p>0.05)$. In the present study, humidity differed $(\mathrm{p}<0.05)$ between weight classes, reaching $15.61 \%$ higher in Class 5 (above $3.5 \mathrm{~kg}$ ). Amaral (2013), when evaluating the chemical composition of the commercial cut filet of tambaqui in Ariquemes-RO-Brazil, obtained, on average, results similar to those found in this study, however, there is a considerable discrepancy regarding humidity, around $31.07 \%$, which can be explained by the fact that the samples were acquired in open markets, where the exposure of the fish, for long periods to the environment, may have accelerated the exudation of the commercialized cuts, since the fish meat is more sensitive to uncontrolled conditions. However, Lima (2012), when characterizing the chemical composition and evaluating the yield of snapper filets (Piaractus mesopotamicus), also found values close to those described in this work, using average values of three chemical composition determinations.

Souza et al. (2004), when analyzing the centesimal composition of Nile tilapia (Oreochromis niloticus) in a sample of 20 fish classified in class 1 (below $1.2 \mathrm{~kg}$ ) of this study, obtained results within the average described for fish (Oliveira et al., 2019). However, the Nile tilapia in the commercial filet cut, was superior in crude protein content, presenting an average of $25.65 \%$, but a lower lipid content, $2.55 \%$. Simões et al. (2007), studied the physical-chemical, microbiological composition and yield of Nile tilapia filet, found values of chemical composition close to those found by this study, obtained 77.13, 2.60, 19, 36 and 1.09\% for moisture, total lipids, crude protein and mineral matter, respectively.

Bombardelli and Sanches (2018) and Barros et al. (2019), evaluated the body morphometric characteristics, cut yield and centesimal composition of the armed meat (Pterodoras granulosus), found for the filet of the referred species, in the class 1 weight range (below $1.2 \mathrm{~kg}$ ) of this study , bromatological indices, on average, very close to the values found by this study, that is, $76.83 \%$ moisture, $1.08 \%$ mineral matter, $14.49 \%$ crude protein and $3.35 \%$ total lipids; noting that the armado has a low lipid index, as does the Nile tilapia from the aforementioned studies, being characterized as semi-fat fish, according to the classifications given by Almás (1981) and Stansby (1962), respectively.

Caula et al. (2008) verified cholesterol levels and centesimal composition of fish species in the state of Ceará - Brazil, such as snapper (Lutjanus purpureus), Nile tilapia (Oreochromis niloticus), curimatã (Prochilodus cearenses) and whole sardines (Triportheus angulatus), showed centesimal values within the parameters presented by Oliveira et al. (2019), expressing again in low lipid contents, with the exception of the whole sardine which presented $4.6 \%$ of lipids. However, the same authors found $80 \%$ humidity in snapper and Nile tilapia.

When choosing classes 1 and 5 (below 1.2 and over $3.5 \mathrm{~kg}$ ) of the tambaqui rib filet, the consumer will purchase more water than meat, because there will be many losses in the preparation, such as fat, which will with the frozen stored cut losing quality over time (Cartonilho \& Jesus, 2011). The fish with higher levels of lipids, when fresh, have greater palatability and a more pleasant flavor, whereas the opposite occurs when under prolonged freezing (Arbelaéz-Rojas et al., 2002). Barros et al. (2019) analyzing the sensory characteristics of commercial tambaqui cuts described that the rib received the highest scores by its evaluators, being the cut most appreciated by consumers of this species, due to the striking and smooth flavor, good juiciness, tenderness and absence of intramuscular pimples, avoiding accidents in its consumption.

The variation in the chemical composition of the commercial cut of tambaqui ribs in different classes of body weight has long been recognized, and stands out for its high levels of crude protein, 15 to 20\%, and total lipids, 5 to 15\% (Stansby, 1962; Arbelaéz-Rojas et al. 2002). According to Almás (1981) it is possible to classify the weight classes of tambaqui and Nile tilapia in lean, 0.2 to $0.8 \%$ of lipids; semi-fat, 2 to $5.7 \%$ lipids, and fat, 8 to $14 \%$ lipids, with energy values corresponding to these classes of 80 to $160 \mathrm{kcal} / 100 \mathrm{~g}$. 
Cartonilho and Jesus (2011), when analyzing the centesimal composition of fresh cuts of tambaqui, obtained results that are similar to the present study, except for the lipid contents of the commercial cut, so that the cut presented $2.18 \%$ of lipids, being classified as thinfish by the authors. Consequently, this low lipid content may compromise the sensory and organoleptic qualities of the stored fish, such as providing shorter shelf life, because much of the production has been commercialized minimally processed under the name of fresh gutted fish. On the other hand, Cirne et al. (2019), when evaluating the organoleptic characteristics of meat cuts of tambaqui, grouped in classes similar to categories 1 and 4 of this study, did not observe statistical differences ( $p>0.05$ ) of nutritional attributes, neither in terms of color and hydrogen potential.

It is worth mentioning that the chemical composition of the fish varies between species, and within the same species, depending on the period of data collection, types of commercial cuts, quality of feeding, age of the fish and mainly the conditions of cultivation. As a comparison of commercial cuts of tambaquis with 100g portions of other fish species, the class 5 tambaqui filet (over $3.5 \mathrm{~kg}$ ) (Table 1) has a higher protein content than a $100 \mathrm{~g}$ portion of salmon (Salmo salar) $(27 \mathrm{~g} / 100 \mathrm{~g}$ ), cooked cod (Gadus morhua) (25g/100g), tuna (Thunnus albacares) $(23 \mathrm{~g} / 100 \mathrm{~g})$ and Nile tilapia filet (Oreochromis niloticus) (21/100g) (Babolato et al., 1994; Usydus et al., 2011). The other weight classes of the tambaqui filet presented contents similar to these commercial cuts, however, they presented a higher lipid content than salmon $(9 \mathrm{~g} / 100 \mathrm{~g})$, cooked cod $(1 \mathrm{~g} / 100 \mathrm{~g})$, tuna $(1 \mathrm{~g} / 100 \mathrm{~g})$ and filet of tambaqui $(1 \mathrm{~g} / 100 \mathrm{~g})$ (Babolato et al., 1994; Usydus et al., 2011).

The commercial cuts of rib, steak and tambaqui band (Tables 1,2 and 3) in the five weight classes, despite having a lower protein content in relation to the $100 \mathrm{~g}$ portions of salmon, $(9 \mathrm{~g} / 100 \mathrm{~g})$ cooked cod $(1 \mathrm{~g} / 100 \mathrm{~g})$, tuna $(1 \mathrm{~g} / 100 \mathrm{~g})$ and tilapia filet (1g/100g) (Babolato et al., 1994; Usydus et al., 2011), have higher levels of lipids. The commercial tambaqui cuts (Tables 1 to 4$)$ in the five weight classes have a higher protein content than portions of liver and chicken wings $(17 \mathrm{~g} / 100 \mathrm{~g})$, however, lower contents in relation to commercial thigh cuts $(28 \mathrm{~g} / 100 \mathrm{~g})$ and frank breast $(32 \mathrm{~g} / 100 \mathrm{~g})$ (Torres et al., 2000; Bastianelli et al., 2010).

The commercial tambaqui cuts (Tebelas 1 to 4 ) despite having lower protein contents than beef and pork cuts, such as pork ribs $(30.2 \mathrm{~g} / 100 \mathrm{~g})$, pork loin $(35.5 \mathrm{~g} / 100 \mathrm{~g})$, beef stiff $(31.9 / 100 \mathrm{~g})$, rump $(31.8 \mathrm{~g} / 100 \mathrm{~g})$ and beef sirloin $(37.5 \mathrm{~g} / 100 \mathrm{~g})$, have higher levels of lipids than beef cuts against filet $(1.44 \mathrm{~g} / 100 \mathrm{~g})$, rib $(0,68 \mathrm{~g} / 100 \mathrm{~g})$, rump steak $(1.95 \mathrm{~g} / 100 \mathrm{~g})$, rump $(1.33 \mathrm{~g} / 100 \mathrm{~g})$ and beef tenderloin $(1.34 \mathrm{~g} / 100 \mathrm{~g})$, and also greater amounts of lipids than wings $(1.2 \mathrm{~g} / 100 \mathrm{~g})$ and chicken breast $(0.62 \mathrm{~g} / 100 \mathrm{~g})$ (Cunha, 2012; Bridi, 2013; Su et al., 2014).

Comparing the content of mineral matter (Tables 1 to 4), with the exception of class 5 (over $3.5 \mathrm{~kg}$ ) of the band and filet cuts of tambaqui, all other cuts in the different classes have more mineral matter than $100 \mathrm{~g}$ portions of chicken breast and leg $(1.2 \mathrm{mg} / 100 \mathrm{~g})$, turkey breast and leg $(1.2 \mathrm{mg} / 100 \mathrm{~g})$, pork fat $(0.7 \mathrm{mg} / 100 \mathrm{~g})$ and beef fat $(0.1 \mathrm{mg} / 100 \mathrm{~g})$ (Roça, 2012). It is worth noting that it is not interesting for the industry to sell very thin or even very fat fish. Because the amount of fat is important for commercialization, since the good amount of lipids provides meat tenderness, but in excessive amounts it can cause health problems to the consumer (Hautrive et al., 2012), because meats with large amounts of saturated fat are harmful due to the LDL cholesterol action in the body, that is, it loads the cholesterol particles from the liver and from other places to the arteries (Siqueira et al., 2018).

However, fish fat is healthy when consumed properly because it has a balanced percentage of polyunsaturated fatty acids that are essential to human health, that is, human beings are not able to produce them. The examples are omega-3 (linolenic acid) and omega-6 (linoleic acid) (Hautrive et al., 2012). The omega-3 fatty acid is found mainly in fish and fish oils.

\section{Conclusion}

The class 4 (from 2.41 to $3.5 \mathrm{~kg}$ ) was the most efficient weight category for production and commercialization. Because the tambaqui of this class stood out as for the nutritional components in the different commercial cuts, of rib, steak, 
filet and band. As for market and consumption parameters, class 4 also stands out, because its centesimal levels are interesting for the industry, as well as for the wholesale and retail, and above all, for the consumer, since their nutritional attributes are presented available and satisfactory to the market.

\section{References}

Almás, K. A. (1981). Chemical and Microbiology of fish and fish processing. Section of Fish Bioquemistry. Department of Biochemistry. Norwegian Institute of Technology. Norway: University of Throndhein, 1981. 183p.

Almeida, L. C., Lundstedt, L. M., \& Moraes, G. (2006). Digestive enzyme responses of tambaqui (Colossoma macropomum) fed on different levels of protein and lipid. Aquaculture Nutrition, 12(6), 443-450. 10.1111/j.1365-2095.2006.00446.x

Arbelaéz-Rojas, G. A., Fracalossi, D. M., \& Fim, J. D. I. (2002). Body composition of tambaqui, Colossoma macropomum, and matrinxã, Bryconcephalus, in intensive cultivation systems, in igarapé, and semi-intensive, in nurseries. Brazilian Journal of Animal Science, 3, $1059-1069$.

Babolato, E. S. G., Carvalho, J. B., Mello, M. R. P. A., Tavares, M., Campos, N. C., Pimentel, S. A., \& Moraes, C. (1994). Proximate composition of fatty acids and caloric value of five species of marine fish from different seasons. Revista do Instituto Adolfo Lutz, 54(1), 27-35.

Baldisserotto, B. (2013). Fisiologia de peixes aplicada à piscicultura. (3th. ed.): Editora UFSM, 2013.

Barros, F. A. L., Brito, M. A. S., Silveira, D. S., Brabo, M. F. \& Cordeiro, C. A. M (2019). Morphometric characteristics, cutting yields and centesimal composition of hybrid tambacu. Agrarian, 12(43), 89-96. 10.30612/agrarian.v12i43.8132

Bastianelli, D., Bonnal, L., Juin, H., Mignon-Grasteau, S., Davrieux, F., \& Carré, B. (2010). Prediction of the Chemical Composition of Poultry Excreta by near Infrared Spectroscopy. Journal of Near Infrared Spectroscopy, 18(1), 69-77. 10.1255/jnirs.864

Bombardelli, R. A., \& Sanches, E. A. (2018). Evaluation of body morphometric characteristics, cut yield and centesimal composition of the meat of the armada (Pterodoras granulosus). Bulletin of Animal Husbandry, 34(2), 221-229.

Botelho, H. A., Costa, A. C., Fernandes, E. M., \& Freitas, R. T. F. (2017). Bromatological analysis of filet pacu (Piaractus mesopotamicus), pirapitinga (Piaractus brachypomum) and tambaqui (Colossoma macropomum). Journal of Veterinary Science and Public Health, 5(2), 158-165. 10.4025/revcivet.v4i2.37022

Brabo, M. F., Pereira, L. F. S., Santana, J. V. M., Campelo, D. A. C., \& Veras, G. C. (2016). Current scenario of fish production in the world, Brazil and Pará State: emphasis on aquaculture. Acta Fish, 4(2), 50-58. 10.2312/ActaFish.2016.4.2.50-58

Bridi, A. M. (2013). Beef consumption and human health: convergences and divergences. Dissertation (Master in Food Science), Universidade Estadual de Londrina, Brazil.

Brum, A. A. S., Arruda, L. F. A., Arce, \& M. A. B. R. (2009). Extraction methods and quality of the lipid fraction of vegetable and animal samples. Revista Química Nova, 32(4). 10.1590/S0100-40422009000400005

Cartonilho, M. M., \& Jesus, R. S. (2011). Quality of frozen cuts of cultivated tambaqui (Colossoma macropomum, Cuvier, 1818). Brazilian Agricultural Research, 46(4), 344-350. 10.1590/S0100-204X2011000400002

Cavali, J., Dantas Filho, J. V., Nóbrega, B. A., Andrade, L. H. V., Pontuschka, R. B., Gasparotto, P. H. G., Francisco, R. S., Campeiro Junior, L. D., \& Porto, M. O. (2020). Benefits of adding virginiamycin to Arapaima gigas (Schinz, 1822) diet cultivated in the Brazilian Amazon. Scientifica. 10.1155/2020/5953720

Caula, F. C. B., Oliveira, M. P., \& Lima, E. (2008). Cholesterol content and proximate composition of some fish species in the state of Ceará. Food Science and Technology, 28(4), 959-963.

Cirne, L. G. A., Souza, W. S., Brito, P. F., Souza, J. R., Feltran, R. B., Santos, M. R., Andrade, E. G., Silva A. J. L., Jesus, R. S., \& Pereira, S. L. A. (2019). Quality of tambaqui meat slaughtered with different weight classes. Bulletin of Animal Husbandry, 76. 10.17523/bia.2019.v76.e1459

Costa A. L. S., Rodrigues, M. S., \& Ricci, F. (2015). Characterization of fish farming in the region of Ariquemes, in the state of Rondônia. Journal of Agrarian Geography, 10(20), 512-537.

Costa Júnior, J. M. F., Silva, C. I. M., Lima, A. S., Rodrigues Junior, D., Silveira, C. L., Souza, G. S., \& Pinheiro, M. C. N. (2018). Levels of mercury found in hair and fish consumption of riverine communities in the Tapajós region of the Brazilian Amazon. Ciência \& Saúde Coletiva, 23(3). 10.1590/1413-81232018233.09492016

Cruz, C. D. (2013). Genes: a software package for analysis in experimental statistics and quantitative genetics. Acta Scientiarum Agronomy, 35(3), 271-276. 10.4025/actasciagron.v35i3.21251

Cunha, L. P. (2012). Analysis of the mandatory nutritional information of fresh beef meat. Monograph (Graduation in Pharmacy), Universidade do Extremo Sul de Santa Catarina, Brazil.

Dantas Filho, J. V., Cavali, J., Nunes, C. T., Nóbrega, B. A., Gasparini, L. R. F., Souza, M. L. R., Porto, M. O., Rosa, B. L, Gasparotto, P. H. G. \& Pontuschka, R. B. (2021). Proximal composition, caloric value and price-nutrients correlation of comercial cuts of tambaqui (Colossoma macropomum) and pirarucu (Arapaima gigas) in diferente body weight classes (Amazon: Brazil). Research, Society and Development, 10(1), p. e23510111698. 10.33448/rsdv10i1.11698.

Detmann, E., Souza, M. A., Valadares Filho, S. C., Queiroz, A. C., Berchelli, T. T., Saliba, E. O. S., Cabral, L. S., Pina, D. S., Ladeira, M. M., \& Azevedo, J. A. G. (Eds.). (2012). Métodos para análise de alimentos - INCT - Ciência Animal. Visconde do Rio Branco: Suprema, 2012. 
Dória, C. R. C., Ruffino, M. L., Hijazi, N. C., \& Cruz R. L. (2012). The Commercial fisheries of the Madeira river basin in the Rondônia state, brazilian Amazon. Acta Amazonia, 42(1). 10.1590/S0044-59672012000100004

FAO. Food and Agriculture Organization of the United Nations. (2018). Fishery and aquaculture statistics 2018. Roma: FAO.

IBGE. Instituto Brasileiro de Geografia e Estatística. (2017). Produção da pecuária municipal 2016: 44, 1-51.

Hautrive, T. P., Marques, A. C., \& Kubota, E. H. (2012). Proximate composition of ostrich meat. Journal Food and Nutrition, 23(2), 327-334.

Lima, C. A., \& Goulding, M. (1998). Os frutos do tambaqui : ecologia, conservação e cultivo na amazônia. Manaus: Sociedade Civil Mamirauá.

Lima, L. K. F., Noleto, S. S., Santos, V. R. V., Luiz, D. B., \& Kirschni, P. G. (2018). Yield and centesimal composition of tambaqui (Colossoma macropomum) by different processing forms and weight categories. Brazilian Journal of Animal Hygiene and Health, 12(2), 223-235.

Lima, M. M., Mujica, P. I. C., \& Lima, A. M. (2012). Chemical characterization and yield evaluation in caranha filets (Piaractus mesopotamicus). Brazilian Journal of Food Technology, 15, 41-46.

Martins, L. P., Franco, V., Dantas Filho, J. V., \& Freitas, C. O. (2020). Economic viability for the cultivation of tambaqui (Colossoma macropomum) in na excavated tank in the municipality of Urupá, Rondônia-Brazil. Revista de Administração e Negócios da Amazônia, 12(2). 10.18361/2176-8366/rara.v12n2p6489

Meante, R. E. X., \& Dória, C. R. C. (2017). Characterization of the fish production chain in the state of Rondônia: development and limiting factors. Revista de Administração e Negócios da Amazônia, 9(4), 164-181. 10.18361/2176-8366/rara.v9n4p164-181

Menezes, B., Fernandes, T. R. C., \& Dória, C. R. C. (2010). Carcass characteristics and performance parameters of tambaqui (Colossoma macropomum, Cuvier, 1818) at different times of cultivation and fed with commercial rations. Bulletin of Animal Husbandry, 36(1), 45-52.

Oliveira, M. O. S., Luiz, D. B., Santos, V. R. V., Oliveira, E. H. S., \& Martins, G. A. S. (2019). Quality and safety aspects of tambaqui (Colossoma macropomum) and painted Amazon (Pseudoplatystoma reticulatum x Leiarius marmoratus). Revista Desafios, 6, 10-16. 10.20873/uft.2359365220196Especialp10

Peixe, B. R. Associação Brasileira da Piscicultura (2020). Anuário 2020: Peixe BR da Piscicultura. 136p.

Porto, M. O., Cavali, J., Medeiros, I. D., Soares, M. O., Dantas Filho, J. V., Ferreira, A. M, Dias, A. A., \& Santana, S. R. (2021). Artificial aeration promotes better zootechnical performance and physiological balance of tambaqui (Colossoma macropomum) cultivated in a system without continuous water flow (Amazon: Brazil). Research, Society and Development, 10(1), p. e32310111759. 10.33448/rsd-v10i1.11759.

Porto, M. O., Oliveira, J. D., Cavali, J., Dantas Filho, J. V., Soares, N. T. D., Gasparotto, P. H. G., \& Ferreira, E. (2020). Food frequency for tambaqui Colossoma macropomum (Cuvier, 1818) grown in an Amazonian Research Center. Revista de Administração e Negócios da Amazônia, 2(1). /10.18361/21768366/rara.v12n1p108-121

Ribeiro, P. S., Vasconcelos, E. Q. L., Souza, A. F. L., Silva Júnior, J. L., \& Inhamuns, A. J. (2018). Physical-chemical and microbiological quality of frozen fish consumed in school meals in the state of Amazonas. Veterinary Medicine Publications, 12(5). 10.22256/pubvet.v12n5a93.1-6

Roça, R. O. (2012). Chemical composition of meat. Botucatu-SP: Department of Agroindustrial Management and Technology. Universidade Estadual Paulista "Julio de Mesquita Filho" (UNESP), Brazil.

Rodrigues, A. P. O. (2014). Nutrition and feeding of tambaqui (Colossoma macropomum). Bulletin of Animal Husbandry, 40(1), $135-145$.

Sales, R. O. \& Maia, E. L. (2013). Chemical composition and classes of lipids in freshwater fish tambaqui, Colossoma macropomum. Brazilian Journal of Animal Hygiene and Health, 7(2), 31-44. 10.5935/19812965.20130009.

Silva, J. A. M., Pereira Filho, M., \& Oliveira, M. I. P. (2005). Seasonal variation of nutrients and energy in tambaqui’s (Colossoma Macropomum, Cuvier, 1818) natural food. Brazilian Journal of Biology, 60(4), 599-605. 10.1590/S0034-71082000000400009

Simões, M. R., Ribeiro, C. D. F. A., Ribeiro, S. D. C. A., Park, K. J., \& Murr, F. E. X. (2007). Physicochemical and microbiological composition and yield of thai-style tilapia filets (Oreochromis niloticus). Food Science and Technology, 27(3), 608-613.

Siqueira, K. B., Nunes, R. M., Borges, C. A. V., Pilati, A. F., Marcelino, G. W., Gama, M. A. S., \& Silva, P. H. F. (2018). Cost-benefit ratio of the nutrients of the food consumed in Brazil. Ciência \& Saúde Coletiva. 25(3): 1129-1135.

Souza, M. L. R., Baccarin, A. E., Viegas, E. M. M., \& Kronkas, S. N. (2004). Smoked whole Nile tilapia (Oreochromis niloticus) and filet: aspects related to organoleptic characteristics, proximate composition and losses in processing. Brazilian Journal of Animal Science, 33(1), 27-36.

Su, H., Sha, K., Zhang, L., Zhang, Q., Xu, Q., Zhang, R., Li, H., \& Sun, B. (2014). Development of near infrared reflectance spectroscopy to predict chemical composition with a wide range of variability in beef. Meat Science, 98(2), 110-114. 10.1016/j.meatsci.2013.12.019

Stansby, M. E. (1986). Proximate composition of fish. In: Hee, E. \& Kreueer, R. Fish in Nutrition. London, Fishing News Ltda., 447p.

Torres, E. A. F. S., Campos, N. C., Duarte, M., Garbelotti, M. L., Phillippi, S. T., \& Rodrigues, R. S. M. (2000). Proximate composition and caloric value of foods of animal origin. Food Science and Technology, 20(2). 10.1590/S0101-20612000000200003

Usydus, Z., Szlinder-Richert, J., Adamczyk, M., \& Szatkowska, U. (2011). Marine and farmed fish in the Polish market: Comparison of the nutritional value. Food Chemistry, 126(1), 78-84. 10.1016/j.foodchem.2010.10.080

Valenti, W. C., Barros, H. P., Moraes-Valenti, P., Bueno, G. W., \& Cavalli, R. O. (2021). Aquaculture in Brazil: past, present and future. Aquaculture Reports, 19, p.100611. 